\title{
Attempted Treatment of Trachoma with Idoxuridine
}

\author{
SHIONA SOWA,* M.B., D.o.; J. SOWA,* B.A., M.sc.
}

Treatment with idoxuridine (5-iodo-2'-deoxyuridine ; I.D.U.) of experimental herpes simplex keratitis in rabbits (Kaufman, Nesburn, and Maloney, 1962 ; Corwin, Okumoto, Thygeson, and Jawetz, 1963) was followed by reports of its successful use in herpes simplex in man (Kaufman, Martola, and Dohlman, 1962 ; Corrigan, Gilkes, and Roberts, 1962; Havener and Wachtel, 1963 ; Maxwell, 1963). Other authors, though less enthusiastic, concede the value of I.D.U. in selected cases (Davidson, 1962 ; Luntz and MacCallum, 1963). Hall-Smith, Corrigan, and Gilkes (1962) found the drug effective for treating cutaneous herpes simplex, whereas Burnett and Katz (1963) found it useless. Loddo, Muntoni, and Ferrari (1963) reported that I.D.U. inhibited vaccinia in vitro but not poliovirus type 1 or Coxsackie virus type B3, which are R.N.A. viruses.

So far, only D.N.A. viruses have been shown to be susceptible to I.D.U. Since the trachoma/inclusion conjunctivitis (TRIC) agents contain both D.N.A. and R.N.A., it was of interest to study the influence of this drug on trachoma, both in man and in infected chick embryos.

\section{Materials and Methods}

I.D.U. preparations were provided by Smith Kline and French Laboratories Ltd. in the form of $0.5 \%$ ophthalmic ointment and $0.1 \%$ ophthalmic solution.

Isolation of TRIC agent in chick embryos and demonstration of inclusion bodies were done as described by Sowa and Collier (1960).

Patients.-The trial group consisted of seven boys and five girls aged 2 to 7 years. On the day of admission all were diagnosed as trachomatous by slit-lamp examination and by isolating TRIC agent in chick embryos; in most of them inclusion bodies were also demonstrated in the conjunctiva (see Table). During the experiment patients were examined daily by loupe; slit-lamp and virological examinations were repeated both at the end of treatment and two weeks later.

Clinical Treatment.-I.D.U. ointment was applied to the lower conjunctival fornix four times daily at four-hourly intervals for 10 days.

Sensitivity Tests in Chick Embryos.-A yolk sac heavily infected with a freshly isolated strain of TRIC agent was homogenized with an equal volume of sucrose/potassium glutamate solution (Bovarnick, Miller, and Snyder, 1950) containing neomycin 10,000 units $/ \mathrm{ml}$. (to which this agent is completely resistant); to tenfold dilutions of this suspension equal volumes of $0.1 \%$ I.D.U. solution were added ; the mixtures were inoculated immediately in $0.6-\mathrm{ml}$. amounts into groups of four 6-day chick embryos. Control suspensions without I.D.U. were inoculated into other embryos.

\section{Results}

Influence on Clinical Trachoma.-The clinical findings before treatment are given in the Table; they did not change appreciably throughout the trial period. All subjects remained

* M.R.C. Trachoma Research Unit, Medical Research Council Laboratories, Fajara, Gambia. virus-positive throughout the trial, as shown by isolation of TRIC agent and/or demonstration of inclusion bodies.

Test in Chick Embryos.-At dilutions of TRIC agent suspension up to and including $10^{-4}$, growth of the agent was not inhibited by a final concentration of $0.05 \%$ I.D.U.

Treatment of Clinical Trachoma with I.D.U.

\begin{tabular}{|c|c|c|c|c|c|c|c|c|}
\hline \multirow{3}{*}{$\begin{array}{l}\text { Case } \\
\text { No. }\end{array}$} & \multirow{3}{*}{$\begin{array}{l}\text { Tra- } \\
\text { choma } \\
\text { Stage }\end{array}$} & \multirow{3}{*}{ Clinical Signs Before Treatment* } & \multicolumn{6}{|c|}{ Laboratory Findings } \\
\hline & & & \multicolumn{2}{|c|}{$\begin{array}{l}\text { Before } \\
\text { Treat- } \\
\text { ment }\end{array}$} & \multicolumn{2}{|c|}{$\begin{array}{l}\text { Imme- } \\
\text { diately } \\
\text { after } \\
\text { Treat- } \\
\text { ment }\end{array}$} & \multicolumn{2}{|c|}{$\begin{array}{c}\text { Two } \\
\text { Weeks } \\
\text { after } \\
\text { Treat- } \\
\text { ment }\end{array}$} \\
\hline & & & 节 & 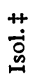 & 㤩 & 灾 & 苟 & 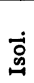 \\
\hline $\begin{array}{l}33 \\
16 \\
18 \\
19 \\
28 \\
09 \\
10 \\
34 \\
38 \\
M 2 \\
M 3 \\
\text { M7 }\end{array}$ & $\begin{array}{l}\text { III } \\
\text { II } \\
\text { II } \\
\text { III } \\
\text { II } \\
\text { III } \\
\text { III } \\
\text { III } \\
\text { III } \\
\text { II } \\
\text { II } \\
\text { II }\end{array}$ & $\begin{array}{l}+\mathrm{C}+\mathrm{F}++\mathrm{PV}^{2}++\mathrm{SPK} \\
+\mathrm{F}+\mathrm{PV}+\mathrm{SPK}^{1}+\mathrm{HP} \\
++\mathrm{F}+\mathrm{PV}^{2}+\mathrm{SPK}+\mathrm{HP}+\mathrm{LF} \\
+\mathrm{C}+\mathrm{F}++\mathrm{PV}^{3}++\mathrm{SPK}+\mathrm{HP}+\mathrm{LF} \\
++\mathrm{F}+\mathrm{P}+\mathrm{HP}+\mathrm{LF} \\
++\mathrm{C}+\mathrm{F}+\mathrm{PV}^{2}++\mathrm{LF} \\
+\mathrm{C}++\mathrm{F}+\mathrm{P}+\mathrm{HP} \\
+\mathrm{C}++\mathrm{F}++\mathrm{PV}^{2}+\mathrm{SPK}+\mathrm{HP} \\
++\mathrm{C}+\mathrm{F}+\mathrm{PV}^{8}+\mathrm{HP} \\
++\mathrm{F}++\mathrm{PV}^{1}+\mathrm{HP}+\mathrm{LF} \\
++\mathrm{F}++\mathrm{PV}^{2}+\mathrm{HP} \\
+++\mathrm{F}+++\mathrm{PV}^{2}++\mathrm{SPK}\end{array}$ & $\begin{array}{l}+ \\
+ \\
+ \\
+ \\
+ \\
+ \\
+ \\
+ \\
+ \\
+ \\
+ \\
+\end{array}$ & $\begin{array}{l}+ \\
+ \\
+ \\
+ \\
+ \\
+ \\
+ \\
+ \\
+ \\
+ \\
+ \\
+\end{array}$ & $\begin{array}{l}+ \\
\pm \\
+ \\
+ \\
+ \\
\pm \\
+ \\
+ \\
+ \\
+ \\
+\end{array}$ & $\begin{array}{l}+ \\
+ \\
+ \\
+ \\
+ \\
+ \\
+ \\
+ \\
+ \\
+ \\
+ \\
+\end{array}$ & $\begin{array}{l}+ \\
+ \\
+ \\
+ \\
+ \\
+ \\
+ \\
+ \\
+ \\
+ \\
+\end{array}$ & $\begin{array}{l}+ \\
+ \\
+ \\
+ \\
+ \\
+ \\
+ \\
+ \\
+ \\
+ \\
+ \\
+\end{array}$ \\
\hline
\end{tabular}

*Wld. Hlth Org. techn. Rep. Ser., 1952, No. 59

t Inclusion bodies.

I Isolation in chick embryos.

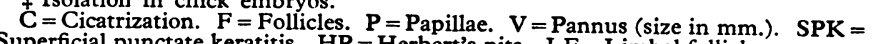
Superficial punctate keratitis. $H P=$ Herbert's pits. $\mathbf{L F}=$ Limbal follicles.

\section{Comment}

In the concentrations tested idoxuridine did not influence the course of active trachoma, and failed to eliminate the causal agent from the conjunctiva. Pressure of other work did not permit elaborate sensitivity tests in chick embryos, but the result of one experiment supported the clinical observations. These findings are perhaps not surprising in view of the fact that the aetiological agent of trachoma is not a true virus and resembles more closely an intracellular form of bacterium.

We acknowledge with thanks the kindness of Messrs. Smith Kline and French in supplying I.D.U. preparations; we are also grateful to Mr. M. Race for technical assistance, and to the medical and nursing staff of the M.R.C. Laboratories, Gambia, for their co-operation.

\section{REFERENCES}

Bovarnick, M. R., Miller, J. C., and Snyder, J. C. (1950). ₹. Bact., 59, 509.

Burnett, J. W., and Katz, S. L. (1963). F. invest. Derm., 40, 7

Corrigan, M. J., Gilkes, M. J., and St. Clair Roberts, D. (1962). Brit. med. f., 2, 304.

Corwin. M. E., Okumoto, M., Thygeson, P., and Jawetz, E. (1963). Amer. F. Ophihal., 55, 225.

Davidson, S. I. (1962). Lancet, 2, 1326.

Hall-Smith, S. P., Corrigan, M. J., and Gilkes, M. J. (1962). Brit. med. f., 2, 1515 . Havener, W. H., and Wachtel, J. (1963). Amer. F. Ophthal., 55, 234.
Kaufman, H. E., Martola, E.-L., and Dohiman, C. (1962). Arch. Ophthal., 68. 235.

Nesburn, A. B., and Maloney, E. D. (1962). Ibid., 67, 583. Loddo, B., Muntoni, S., and Ferrari, W. (1963). Nature (Lond.), 198,
510.

Luntz, M. H., and MacCallum, F. O. (1963). Brit. f. Ophthal., 47, 449.

Maxwell, E. (1963). Amer. ₹. Ophthal., 55, 237.

Sowa, J., and Collier, L. H. (1960). F. Hyg. (Camb.), 58, 99. 